\title{
Religion, politics and the meaning of self-sacrifice for Tibet
}

\section{Introduction}

This paper analyses opinions of political self-sacrifice ${ }^{1}$ amongst Tibetan refugees, and explores their meaning for wider debates on the evolving relationship between religion and politics in the Tibetan national struggle. This is a particularly pertinent question at present, given the recent prevalence of self-immolation in Tibet and connected debates about whether such protests 'belong to the religious or political sphere' (Buffetrille 2012: 7). Does approval of self-sacrificial political methodology indicate a secularisation process (Ardley 2002), or is it simply reflective of the natural fluidity of religion's political influence? This paper supports the latter position, and seeks to explore the current (and potential future) nature of this dynamic relationship further.

It offers insights into the Tibetan political movement through an in-depth study of one refugee community. Evidence is presented from fieldwork in Dharamsala, a Tibetan settlement in north-western India home to the Dalai Lama and approximately eight thousand refugees. Local opinions about self-sacrificial political methods were sought over six months in 2012, through both participant observation and more structured methods including questionnaires and interviews (104 of each). It must be noted that this paper is therefore a case study of this geographical population; it cannot claim to represent the views of the entire Tibetan diaspora. ${ }^{2}$ Nevertheless, the choice of Dharamsala is reflective of its status as the hub of Tibetan politics in exile, being the site of the government-in-exile and the base location for most of the prominent activist groups' headquarters.

In terms of the paper's structure, the first section offers a brief overview of the religion-politics relationship in traditional Tibetan culture. The second part then explores the Dalai Lama's views of self-sacrifice, explaining why he rejects it on religious grounds. The third section discusses how political self-sacrifice has been employed by Tibetans in recent years, and considers refugees' positive responses to

\footnotetext{
1 The term political self-sacrifice, also referred to as self-suffering, is used to mean harm that is willingly accepted, encouraged or inflicted upon the self for political purposes. This study refers in particular to hunger striking and self-immolation.

${ }^{2}$ Naturally, this study can make no claim to represent the ideas of Tibetans inside Tibet either. Political restrictions in Tibet make this type of research impossible within its borders.
} 
this. The paper then moves on to pose the next logical question: should the increasing prevalence of political self-sacrifice therefore be considered indicative of a secularising process in the Tibetan context? It is argued that while this may be the case in activist organisations, it is not a sound interpretation for the general population more broadly. Furthermore, it is argued that - contrary to logical inference - this does not imply a straightforward reduction of faith in the Dalai Lama (or his politics) either.

The last section of the paper considers the implications of the research findings for the future of resistance politics in Dharamsala. Although it is impossible to make definitive predictions, it is submitted that the most likely outcome is not secularisation, but perhaps a reconfiguring of religious ideas that maintains the image - if not always the philosophy - of the Dalai Lama.

\section{The role of religion in Tibetan politics in exile}

Before the incremental Chinese occupation of Tibet during the 1950s, the Tibetan governance system was chos-srid zung-'brel - 'religion and politics combined' Barnett (1994: 245). For several centuries, the Dalai Lama (he has had fourteen incarnations so far) was 'the only unquestioned leader of the Tibetan people' (Kolas 1996: 57). This leadership continued in the government-in-exile after the current Dalai Lama fled Chinese-occupied Tibet in 1959, followed by many Tibetans who traversed the Himalayas on foot to reach sanctuary in South Asia. The Tibetan national struggle has been waged from Dharamsala since then, spearheaded by the Dalai Lama and guided by his spiritual perspective on politics.

This perspective has shaped a political movement internationally famed and admired for its rejection of violence and its willingness to compromise. For instance, the fundamental goal of national independence was replaced by regional autonomy as a result of this perspective, and various methods popular in other nonviolent movements have been rejected for being coercive as opposed to being based on the persuasive power of friendship: even boycotts have been ruled out of the official methodology. ${ }^{3}$

\footnotetext{
${ }^{3}$ At an audience at Cambridge University in 2013, a student asked if the Dalai Lama would support an economic and cultural boycott of China. He replied in the negative, stating that he would consider it unfair to target the Chinese masses rather than the state. 'Better to bring
} 
However, based on Tibetan refugees' political activities during the 1990s, Jane Ardley (2002) argues that the increasing acceptance by Tibetans of political selfsacrifice, which the Dalai Lama explicitly rejects, indicates that they are undergoing a process of political secularisation. She further submits that this could (and should) culminate in the removal of the Dalai Lama's influence from people's political thinking altogether, the ejection of religion from political institutions, and the subsequent embrace of standard nonviolent resistance methods (i.e. boycotts, civil disobedience and self-sacrificial methods such as hunger striking) and perhaps even violent ones as well (Ardley 2002).

Since Ardley (2002) made these arguments, the state of chos-srid zung-'brel has undergone major changes; the Dalai Lama implemented a gradual process of democratization in the exile polity, culminating in his official political retirement in 2011. The government-in-exile is now headed solely by a democratically elected Prime Minister. Nonetheless, the government-in-exile still bases its policies on the Dalai Lama's political framework; in contrast to Ardley's (2002) predictions, his selfremoval from politics has not yet led the new democratic government to instate an official demand for national sovereignty, for example. However, Ardley's (2002) linkage of Tibetans' self-sacrificial political methods with the concept of secularisation, and in particular with the Dalai Lama's decreasing political relevance for Tibetans in exile, remains interesting. Given that her predictions were made on the back of limited levels of self-sacrifice in the Tibetan movement, and the fact that recent years have seen an unprecedented proliferation of self-sacrifice, it seems pertinent now to explore her arguments further.

The rest of this paper will seek to respond to the idea that Tibetan refugees' widespread approval of political self-sacrifice implies their recognition that religion 'has hindered those struggling to free Tibet' (Ardley 2002: 166) and moreover that it represents an express rejection of the Dalai Lama's political opinions, foreshadowing

China into the mainstream of world affairs and try to influence it on the basis of friendship', he said (see http://www.dalailama.com/news/post/936-speaking-about-non-violence-and-thepath-to-peace-and-happiness-in-cambridge). Of course, sceptics would question the extent to which such a statement may actually result from his awareness that international support in such efforts would not be forthcoming. In terms of realpolitik, therefore, it may be regarded as more sensible for the Tibetan leadership to reject such ideas, and in doing so to maintain the (internationally admired) image of Tibetans as innately friendly/non-confrontational. 
a complete reconfiguration of Tibetan nationalism in exile. It begins now with an analysis of the Dalai Lama's philosophy regarding self-suffering.

\section{Self-sacrifice in the Dalai Lama's nonviolent politics}

A superficial reading of Buddhist philosophy immediately points to the insistence upon nonviolence in the Five Precepts, which are essentially the core code of conduct for Buddhists. ${ }^{4}$ For most interpreters, moreover, this doctrine encapsulates restrictions on harming one's own body. However, beyond this basic observation there do exist other reasons within this religious system for rejecting self-harm. For example, Mahayana Buddhism (the form dominant in Tibet) teaches that the aim of all spiritual practitioners should be to help other sentient beings to achieve freedom from suffering. Clearly, becoming seriously physically compromised or even dying would be an obvious obstacle to that goal. Samdhong Rinpoche, a monk and twoterm former Prime Minister of the Dalai Lama's government-in-exile, is a strong proponent of Tibetan satyagraha. ${ }^{5}$ Nevertheless, he offers the following opinion about self-sacrifice:

'voluntary self-torture is not good. This is because the human body is very precious and it is the only vehicle through which we can do work.

If that vehicle is denied of its physical and biological needs it will become weak... That is not permissible in the Buddhist perception' (quoted in Ardley 2002: 48).

Likewise, according to the Dalai Lama's religious interpretation, the fundamental Buddhist concept of interdependence also helps to negate the practice of political self-suffering. This doctrine teaches that if I harm myself or actively encourage harm upon myself, then that harm will be reflected across all sentient beings, who are indivisibly connected to me. Put bluntly, from the Dalai Lama's perspective violence is violence irrespective of both the target (others or the self) and the form (any type of intentional harm is included), and it is unacceptable in political struggles.

\footnotetext{
${ }^{4}$ The Precepts are a set of duties instructing Buddhists to refrain from particular actions (do not kill, do not take what is not willingly given, do not engage in sexual misconduct, do not speak falsely, do not use intoxicants).

5 Mahatma Gandhi termed his nonviolent political approach satyagaraha, which included a range of methods now standard in most nonviolent resistance movements. One essential component of it was self-suffering (viewed from a modernised Hindu perspective of tapas, or penance). For more information see Gandhi (2005); Saxena (1976).
} 
All of this notwithstanding, however, Mahayana Buddhism can be interpreted to offer ways around these restrictions. The relevant doctrine here is that of 'skilful means', which states that ordinary codes of conduct and moral rules can be bypassed by an altruistic actor who seeks to benefit others. One man may be killed to save many, for example, and a person may sacrifice her own life in order to help others in drastic circumstances. Historically this doctrine has been manipulated to justify an enormous range of violent behaviour by Buddhists (Jerryson \& Juergensmeyer 2010), including Japanese Zen warriors (Victoria 1997, 2010) and even terrorist groups (Schmithausen 1999). It was also invoked by the Fifth Dalai Lama of Tibet, who cited skilful means to justify his war against rival Buddhist factions (Maher 2010).

However, Ives (2002) suggests that such use of the doctrine has been inherently inappropriate, arguing that the capacity to make such decisions lies only with enlightened masters. In the same vein Keown (1992) argues that skilful means are condoned only for the most accomplished spiritual practitioners, those who have overcome ego completely:

'the Lord has taught that what is forbidden may be performed by one who perceives with the eye of knowledge a special benefit to beings therein... But the foregoing [exemption] does not apply to everyone... (Shantideva, quoted in Keown 1992: 151).

Other ancient Mahayana texts appear to support this argument. The Skill in Means Sutra states that an enlightened person's perfect insight into shunyata (emptiness) prevents her from experiencing karmic retribution if she commits acts that would ordinarily be considered morally reprehensible. According to Keown (1992), Shantideva's Siksamuccaya also states that only a bodhisattva with perfect (i.e. enlightened) compassion can break ordinary moral codes without suffering negative consequences. ${ }^{6}$

Nonetheless, there are scholarly detractions from this argument (e.g. Clayton 2006), and it seems reasonable to conclude that the issue is not always entirely clear in the religious literature. There is no 'rule book' that Mahayana Buddhists must follow, and

${ }^{6}{ }^{6}$ Shantideva was an $8^{\text {th }}$ century Buddhist monk, and is generally considered one of the most important contributors to Mahayana Buddhist philosophy. His two most important contributions were the Siksamuccaya and the Bodhicaryavatara, the latter of which the Dalai Lama (1994) has converted into a philosophical guide for modern living. 
there tend to be subtle variations between one text and another (and even between commentaries on the same text). However, it can be asserted that the Dalai Lama's interpretation of this issue is more in line with Keown's (1992) than it is with Clayton's (2006). In order to demonstrate this, I would like to quote at length from an interview that Catherine Ingram (1990: 12-13) conducted with the Dalai Lama:

'Cl: When you first visited Rajghat, the site of Gandhi's memorial in India, you spoke of feeling a commitment to nonviolence. But I've also read a story you tell of a bodhisattva on a boat who became aware that a man on the boat was planning a mutiny which the bodhisattva knew would cause the death of hundreds of people. In compassion for those people, the bodhisattva killed the man who would have caused the death of hundreds, and thereby took on himself the karma of killing.

DL: Of course, yes.

$\mathrm{Cl}$ : Do you think there are times when violence is the appropriate action?

DL: .... In that story, the man had... developed fully as a true bodhisattva. For a person such as that, the altruistic motivation is very, very genuine. With that kind of motivation it is possible to follow some kind of seemingly violent method with confidence, in order to help others. In my case, I am not fully developed in that kind of altruism. Of course, I try. And as time goes by, it is increasing... But, you see, I don't have that certainty or confidence, so it is very risky. The more reliable, the safer thing is complete nonviolence.

$\mathrm{Cl}$ : So unless someone is a fully developed bodhisattva, then complete nonviolence is the better way.

DL: Of course. No doubt.

This conversation leaves us with no doubt about the Dalai Lama's view of skilful means in relation to violence against others, and this is replicated elsewhere with regard to self-sacrifice. In his own discussion of Shantideva, for example, the Dalai Lama (1994: 48) quotes the ancient religious master as saying: 
'Those should not give up their body

Whose compassion is not pure and perfect'.

On this basis, the Dalai Lama further insists that 'we need to protect our bodies, while we purify any selfish motives we may have and increase our altruistic attitude' (1994: 48).

Considering the fact that the Dalai Lama does not yet consider himself capable of this (Ingram 1990), one may safely presume that 'ordinary' people who venerate him as a spiritual leader would not be considered capable either. So where does that leave his nonviolent political strategy?

The Dalai Lama made his feelings on political self-sacrifice very clear in 1998, when he visited a group of Tibetan hunger strikers outside the UN in Delhi:

'I told them that I admire their determination and enthusiasm. But I consider hunger strike unto death as a kind of violence...' (WTNN 1998).

Similarly, in 2007 he wrote to another group of Tibetan hunger strikers attempting to force China into discussions of human rights violations. In a letter dated August $7^{\text {th }}$, thirty-one days after the beginning of that strike, the Dalai Lama commended the protestors on their courage. However, he went on to inform them that their actions were 'a form of violence' and urged them to end their self-imposed suffering immediately, insisting that 'sacrificing the lives of more Tibetan people...is not likely to bring about the positive results we seek.'7

\section{Popular views of political self-sacrifice in Dharamsala}

This part of the paper now considers the views of refugees in Dharamsala, and in doing so it problematises the popular image of a Tibetan exile community united under the Dalai Lama's political and spiritual leadership.

As mentioned earlier, the Tibetan government-in-exile has ruled out most direct action protest techniques. The Dalai Lama has understandably discouraged all resistance activities inside Tibetan borders, since punishments inflicted on so-called

\footnotetext{
${ }^{7}$ See Thinley (2007) for the Dalai Lama's full letter.
} 
'splittists' by the Chinese state are known to be extremely severe (e.g. Gyatso 1997; TCHRD 2014). However, even in exile he has discouraged most nonviolent methods outlined by Gene Sharp (1973) (the most prominent theoretician of nonviolent resistance), thus objecting to techniques popular with other famous religious nonviolent resistors (e.g. Gandhi and Martin Luther King) including boycotts or hunger strikes, for example.

On the other hand, Tibetans have repeatedly demonstrated their willingness to risk their lives for their country's freedom. Inside Tibet, people have risked subtle forms of protest that, if recognised, could result in severe punishment (Barnett 1994). They have also staged open protests at several historical points (especially in the 1980s and in 2008), despite knowing that these would inevitably have life-threatening consequences (see for example Gyatso 1997; Schwartz 1994; Smith Jr. 2010). In exile, Tibetans' most popular protest methods have been peaceful marches and candle-lit vigils. However, one activist organisation in particular - the Tibetan Youth Congress (TYC) - has long been willing to flout the Dalai Lama's instruction, and has staged a number of hunger strikes since the 1970s. Furthermore, these have had an overwhelmingly positive response from the Tibetan refugee population.

\section{i) Hunger strikes}

The first of these was in 1977 outside the Chinese embassy in Delhi. That hunger strike was unexpectedly successful, leading the Indian government at the time to pledge support to the Tibetan independence movement. It also enjoyed widespread popular support, with refugees from all over India and Nepal gathering to 'do their bit for the cause' (Norbu 1998: n.p.). Nevertheless, Dharamsala's leadership publicly condemned this form of action. In 1988 the TYC organised another hunger strike 'to the death,' but the Dalai Lama contacted the strikers personally, asking them to stop, and they did (Norbu 2008).

The most famous of the TYC hunger strikes to date has been the 1998 strike in Delhi mentioned earlier, this time directed at the UN. There were six strikers, with one hundred more lined up to take their places if they died. A TYC press release on March $16^{\text {th }} 1998$ stated: 
'... Considering the very nature of Non-violent struggle of the people of Tibet, Mahatma Gandhiji's Non-violent method of Hunger Strike is the only option that Tibetan people could participate [in]....'

Carole McGranahan, who was conducting fieldwork in numerous Tibetan refugee settlements during this hunger strike, suggests that by aligning themselves with Gandhi in this statement of nonviolent protest, the TYC was offering a 'coded critique of the Dalai Lama' (McGranahan 2010: 192). She also reports that the hunger strikers enjoyed widespread admiration amongst the general refugee population. Throughout India and Nepal, she recalls, Tibetan refugees knew the names and personal histories of all the hunger strikers. However, the 1998 hunger strike situation intensified on April $26^{\text {th }}$ and $27^{\text {th }}$ when the Indian police forcibly moved the strikers to hospital. On the $27^{\text {th }}$, a man named Thubten Ngodup set himself on fire in protest of their removal, and died from his extensive burns two days later.

Afterwards, the government-in-exile encouraged Tibetans not to engage in this type of protest, suggesting that it would be 'embarrassing' for the Indian state. However, Ngodup was hailed a hero by Tibetans. The TYC initiated 'Martyrs Day' in his remembrance, and released a statement lauding his sacrifice:

'We salute the unwavering bravery shown by Mr. Ngodup... The Tibetan people have sent a clear message to the world that they are willing to sacrifice themselves... If the attitude and indifference and lack of support to the issue of Tibet continue, more blood will be shed in the coming days' (quoted in Ardley 2002: 50).

The hunger strikers had attracted widespread admiration, but Ngodup's death inspired an even more potent torrent of positive emotion. A memorial statue of Ngodup has since been erected in Dharamsala at a prominent place on the korra route around the Dalai Lama's temple and residential complex, ${ }^{9}$ songs have been written about him, and Tibetans in North America even hold an annual basketball tournament in his honour (Shakya 2012a).

ii) Self-immolations (2009-present)

\footnotetext{
${ }^{8}$ See www.tyc.org; http://www.rangzen.com/archive/98/03_march/strike/strike.html

${ }^{9}$ Korra is religious circumambulation around a holy site.
} 
For more than ten years, Ngodup remained the only self-immolating martyr for the Tibetan cause. ${ }^{10}$ In 2009, however, a monk inside Tibet followed Ngodup's example by setting himself on fire in protest of the extreme Chinese crackdown on Tibetans that had followed rioting around the 2008 Beijing Olympics (see ICT 2011). ${ }^{11}$ The Tibetan protests in 2008 combined both violent and nonviolent methods, and the state's response was severe; Tapey's Prefecture Ngaba (in what Tibetans call the Amdo region) reportedly saw over twenty sixteen-year-old schoolgirls shot dead by the authorities, for example (Woeser 2012). When the authorities cancelled the mourning ceremony for these people, Tapey ran into the streets in gasoline-soaked robes and set himself alight. Holding up a Tibetan flag and a picture of the Dalai Lama, he was then shot by the police whilst on fire.

Two years later, another monk self-immolated on the same spot, and was beaten to death by the military police. Unlike Tapey's, however, Phuntsog's death set in motion a so-called 'epidemic' of self-immolations which would reach epic proportions in the years to follow. ${ }^{12}$ As of June 2015 there have been 141 self-immolations for the Tibetan cause, the vast majority of which have taken place inside Tibet. The selfimmolators have come from all backgrounds; they represent the monastic and lay communities, men and women, young and middle-aged. They also represent the entire ethnic Tibetan region. ${ }^{13}$

During my fieldwork in 2012, self-immolations were occurring extremely regularly inside Tibet. In Dharamsala, posters and enormous banners hung on buildings and across streets, demonstrating through photographic evidence these people's remarkable 'sacrifice of life for Tibet.' Members of the public had even erected one of

\footnotetext{
10 In 2006, a Tibetan protestor in Mumbai attempted to self-immolate in protest against $\mathrm{Hu}$ Jintao's visit to India. Onlookers managed to put out the flames and saved his life.

11 In March 2008, after the Chinese state blocked a peaceful march by Tibetan monks, a riot broke out in Lhasa. Over 150 other protests (most of which are said to have been nonviolent) then erupted in ethnically Tibetan areas. The government's response involved the deployment of huge numbers of armed forces. Chinese statistics suggest that 19 people were killed in Lhasa, primarily in fires, while Tibetan organisations in exile claim that between 100 and 218 Tibetans were killed by security forces during these demonstrations.

12 The Dalai Lama originally voiced his opinion of the self-immolations in a way that reflected his views of hunger strikes, but as the political situation progressed, he stopped doing so publicly. It is possible that this change in behaviour is at least partly a result of his not wanting to devalue the bravery of the self-immolators, or to give their families cause to worry about their karma, for example. However, he does continue to plead with the public not to engage in these acts, focusing instead on their likely political ineffectiveness against the Chinese state. ${ }^{13}$ For more demographic details, see http://www.savetibet.org/resources/fact-sheets/selfimmolations-by-tibetans/
} 
these posters in the Dalai Lama's temple complex, where local community members and tourists go regularly to pray. There was a sense of hushed excitement in the air; everyone seemed to feel that these acts were going to change the Tibetan political situation. People spoke every day of their admiration for the bravery of these people, and wondered how they, in exile, could honour their memories appropriately by continuing their political legacy.

Exiled Tibetans' opinions of the self-immolations are reflective of Vietnamese views of anti-war self-immolations in 1960s Vietnam. When the first of these, Thich Quang Duc, doused himself in gasoline and set himself on fire at a busy intersection in Saigon, the western world responded with horror. Yet in a letter to Martin Luther King, fellow Vietnamese monk Thich Nhat Hanh described this kind of sacrifice as entirely nonviolent, insisting that it is not suicide but 'an act of construction, that is, to suffer and die for the sake of one's people.'14

Ultimately, the central observation here is that while Tibetans in Dharamsala do favour nonviolent political activism, like Gandhi and Thich Nhat Hanh (the founder of Engaged Buddhism) they view self-sacrificial methods as being laudable and effective ways to pursue this. The following results from the questionnaire employed as part of this study sum these points up well:

Fig. 1

\begin{tabular}{|l|l|l|l|l|l|}
\hline Statement & $\begin{array}{l}\text { Strongly } \\
\text { Agree }\end{array}$ & Agree & $\begin{array}{l}\text { Not } \\
\text { Sure }\end{array}$ & Disagree & $\begin{array}{l}\text { Strongly } \\
\text { Disagree }\end{array}$ \\
\hline $\begin{array}{l}\text { Violence is } \\
\text { needed to get } \\
\text { results in the } \\
\text { Tibetan freedom } \\
\text { movement }\end{array}$ & $5.9 \%$ & $11.8 \%$ & $7.8 \%$ & $28.4 \%$ & $46.1 \%$ \\
\hline
\end{tabular}

Fig. 2

\begin{tabular}{|l|l|l|}
\hline Question & Violent & Nonviolent \\
\hline $\begin{array}{l}\text { Are hunger strikes a } \\
\text { violent or nonviolent } \\
\text { method of resistance? }\end{array}$ & $22.2 \%$ & $77.8 \%$ \\
\hline
\end{tabular}

\footnotetext{
${ }^{14}$ For the full text of Thich Nhat Hanh's letter to Martin Luther King see http://www.aavw.org/special_features/letters_thich_abstract02.html
} 


\begin{tabular}{|l|l|l|}
\hline $\begin{array}{l}\text { Are self-immolations a } \\
\text { violent or nonviolent } \\
\text { method of resistance? }\end{array}$ & $22.5 \%$ & $77.5 \%$ \\
\hline
\end{tabular}

Self-sacrificial methods are viewed as positive acts of the purest intention, aimed at improving the lives of all Tibetan people.

Notably, Karin Fierke's (2013) work on political self-sacrifice supports the general view that such acts are socially restorative, legitimating and renewing community dignity and cohesion. Self-sacrifice, she argues, works to reclaim the political capacity/authority of marginalised communities through its evocation of 'sticky' emotion, which affects both local and international audiences. Fierke (2013) therefore suggests that analysis of political self-sacrifice must highlight the concept of performativity; the ability to make a 'speech act' on local and global stages. 'The political weapon', she writes, 'is injury to the body and its performance of a power of resistance.... in which the body speaks against the power of its silencing' (Fierke 2013: 90, italics original).

There is nothing to insist that political self-sacrifice must always be linked to religion in the reassertion of communitas, although Fierke (2013) underscores its common relationship to religious sentiment. Rene Girard, to whom Fierke (2013) refers, has also argued over several decades that the fundamental function of sacrifice is community strengthening, and that its common incorporation in religious systems is reflective of its capacity to achieve this. Although Fierke (2013) disagrees with some of Girard's key assumptions, she notes (as he does) that as cultures have changed, particularly in the face of globalisation, religious practice/belief has stopped being the singular relevant factor leading people towards sacrificial acts. Offering multiple examples of political self-sacrifice, Fierke (2013) notes that while they tend to have religious elements, they are also motivated by factors including international human rights law, and the media's (and I would add mobile technology's) introduction of a global stage for the communication of stark, emotive political messages through the body's most unthinkable performance.

\section{Political self-sacrifice for Tibet: is religion relevant?}

In both local and international understandings, Tibetan religion is tightly linked to the figure of the Dalai Lama (Bentz 2012). However, considering Dharamsala residents' 
open appreciation of resistance techniques that the Dalai Lama rejects, the wellestablished image of a unified refugee community under his leadership would appear to be compromised here. Does this suggest that religion is losing relevance in this community's ideas about political activism?

Certainly for Ardley (2002), Ngodup's self-immolation in 1998 symbolised a critical turn in the Tibetan struggle. In a strong and rather controversial statement at the time, the vice-president of the TYC announced that:

'The Dalai Lama did not achieve anything... Thousands of Tibetans in our homeland have now woken up and will support our type of campaign against China' (quoted in Ardley 2002: 50).

Ardley (2002) interprets such statements from activist groups as being indicative of a significant break with the Tibetan religious establishment and potentially also of a concomitant rise in militant aspirations, and she views this as entirely desirable.

She is undoubtedly correct in her observation that the activist community (including members of the TYC and other influential organisations) inhabits a political space distinct from that of the religion-dominated government-in-exile. In a personal interview with a staff member of the TYC in Dharamsala, for example, I was told that to approach political issues from a spiritual perspective means that 'you can't express real opinion. The heart needs to be separate from the head.' The all-India head of another prominent activist group, Students for a Free Tibet, similarly told me that 'we need to differentiate religion from our politics - it's too limiting.' Thus, many activists believe that spiritual beliefs need to be kept apart from political aims and methods; 'after all,' said another TYC member, 'compassion is not helpful in politics. We have to think in terms of politics: we are political refugees, not religious refugees.'

The suggestion that activist organisations such as the TYC represent a significant break from religious influence is therefore not unreasonable. Nevertheless, it is important not to neglect the complexity of activists' relationship with religion either. In conversation with members of a number of prominent activist organisations in Dharamsala including the TYC, Students for a Free Tibet and Gu Chu Sum, I was told that the sidelining of religious principles is a necessarily pragmatic approach to dealing with the current political situation, which cannot be resolved through means accordant with Buddhist teachings. However, they also regularly emphasised that this sidelining is temporary. For example: 
'Religion is the heart of our culture. We are forced to take steps that our culture does not like... in order to save that culture. Later we will certainly return to our traditions of peace. But first we must win that right by other methods. ${ }^{15}$

To suggest that the membership of these organisations is largely secular, or even in a straightforward process of secularisation, would therefore be somewhat problematic.

I would like to move on now to think about the 'ordinary' people of Dharamsala - by which I mean the people who are not active members of organisations like the TYC or SFT. Firstly, however, consider Ardley's (2002) analysis of the TYC's 1998 hunger strike:

'In many respects the TYC's decision to embark on the hunger strike has crucial implications for the future of the Tibetan struggle. The most important of these is the willingness of some Tibetans to break with the position of the Dalai Lama, and to pursue their own agenda by their own means. In pre-invasion Tibet, such a move would have been unthinkable; in exile society it is still very unusual' (Ardley 2002: $64)$.

She continues:

'The hunger strike was a political act, and religious interpretations should not be applied. In the context of Tibetan politics, this is groundbreaking' (Ardley 2002: 65).

What can we infer from this about ordinary people in Dharamsala today? Firstly, this paper has already demonstrated that support for activities that "break with the position of the Dalai Lama' is not in fact 'very unusual' at all. A substantial majority of ordinary people view both hunger strikes and self-immolations as meritorious nonviolent actions, and openly demonstrate this view with their placement of appreciative banners, public speeches etc. Moreover, they have been supportive of self-sacrificial protest for decades. Referring again to the quotations above, then,

\footnotetext{
${ }^{15}$ Staff member of Gu Chu Sum, an organization for the rehabilitation of political prisoners, in conversation with the author.
} 
does this mean that people in Dharamsala who see fit to "break with the position of the Dalai Lama' are insinuating that 'religious interpretations should not be applied' to their politics?

The answer is no. Although the Tibetan community in Dharamsala clearly favours methods of which the Dalai Lama disapproves, people are firm about their desire to preserve the centrality of religion in their politics. In response to the questionnaire employed for this study, for example, $74 \%$ of respondents stated that politics and religion should be combined. ${ }^{16}$ Further to this, it is notable that even when discussing the self-sacrificial methods so expressly rejected by the Dalai Lama, people still use religious concepts to underpin their approval. For example, as noted above, Carole McGranahan (2010) reports that the 1998 hunger strikers were greatly admired. She quotes her own field notes, recalling her experiences of a religious candlelit procession in the hunger strikers' honour:

'It was phenomenally moving and also frightening and beautiful...[Everyone] did three or four kora and then some went to a gonpa [monastery]...I was in a large group of people and we all had our candles raised high and everyone sang the Tibetan national anthem... there was an element of witness and testimony to it that I cannot quite find the right words for' (McGranahan 2010: 195).

Equally relevant here is her observation that people were in 'awe in recognition of the sacrifice being made and the belief that if you died as a hunger striker you would accumulate a significant amount of [karmic] merit' (McGranahan 2010: 194).

Although McGranahan states unambiguously that the refugee population was aware of the Dalai Lama's views on the matter, they were nevertheless supportive of the hunger strikers, believing them to be acting in both a moral and deeply spiritual fashion. ${ }^{17}$ It is remarkable that, although the Dalai Lama had clearly stated that this was not a Buddhist act, the refugee population nevertheless perceived it as such.

Reflecting McGranahan's (2010) findings regarding the hunger strikes, most people to whom I spoke in Dharamsala in 2012 also viewed self-immolation in religious rather than purely political terms. While members of popular activist organisations

\footnotetext{
16 This figure includes questionnaires completed by activists as well as non-activists. Of activists alone, only $46 \%$ stated that religion and politics should be combined. Although this is a significantly lower figure than the overall total, it is still a substantial percentage, and quite probably a higher figure than would be found in other communities.

${ }_{17}$ The latter was never claimed by members of the TYC, who continue to view their activities as political rather than religious.
} 
often discussed the self-immolations as 'political, not religious' acts, the majority of people took a different view. Candlelit vigils and processions much like that described by McGranahan (2010) above were regular occurrences. Furthermore, when I raised the politics vs. religion distinction, the vast majority of people with whom I spoke referred to the Jataka Tales - particularly to the story of the Hungry Tigress - as 'proof' that political self-sacrifice is a noble and meritorious action within the Tibetan religious framework. ${ }^{18}$ This story is a representation of the 'skilful means' doctrine discussed earlier, and was also referred to by Thich Nhat Hanh in his letter justifying the Vietnamese self-immolations to Martin Luther King. It would appear that Tibetans in Dharamsala believe that skilful means can be used by anyone with the correct intention, despite the fact that the Dalai Lama says otherwise. There is no doubt, moreover, that the religiously appropriate image of self-immolation is furthered by the fact that such a high percentage of the early self-immolators were monks or nuns:

'Of the 45 cases of self-immolation reported until August 5 2012, 34 are monks or nuns, reflecting the framing among Tibetans of monks as the guardians of tradition and as moral leaders'(Shakya 2012a:

34).

Tsering Shakya (2012b: n.p.) is entirely correct, therefore, when he declares that although 'self-immolation as a form of protest is not intrinsically a Buddhist act any more than suicide bombing is an Islamic act', 'for co-nationals and the religious, the act is a statement of faith and identity.' ${ }^{19}$

\footnotetext{
18 The Jataka Tales are a popular collection of parables that detail the Buddha's actions in his past lives, many of which describe situations in which he offered his life in order to appease the suffering of others. Amongst Tibetans in Dharamsala, the most popular Jataka Tale is that of the Hungry Tigress, which tells of a compassionate prince who offered his body as food to a starving tigress so that she would not have to eat her own cubs.

19 Interestingly, Barnett (2012) and Buffetrille (2012) note that self-burning can also be legitimated in Buddhism through reference to the Lotus Sutra, which describes it as a religious offering to the Buddha. Reflecting these ideas, Lixiong's (2012) study of 26 selfimmolators' last words (handwritten notes, videos and verbal communication to friends and family) underscores an intention to make 'acts of religious dedication'. Since the Lotus Sutra was traditionally popular in Chinese rather than Tibetan Buddhism, Barnett (2012) suggests that the self-immolators' ideas could actually have resulted from their exposure to Chinese culture, which still bears marks of its traditional influences in contemporary respect for nationalist martyrdom, for example (see also Shakya 2012a). Notably, however, selfimmolation as religious dedication was not mentioned by Tibetans in Dharamsala during this study. This discrepancy perhaps reflects the differences that exist between those living in the globally connected exile environment and those living inside Chinese-controlled Tibet.
} 
However, although it appears that religion and politics are still tightly linked in the minds of Tibetans in Dharamsala, there is one further issue that must be considered here: 'Shangri-la' pressure. In a nutshell, the popular argument that Tibetans are 'prisoners of Shangri-la' (Lopez 1998) emphasises the fact that, as a small group without resources, Tibetans cannot stand up to Chinese dominance alone, and must therefore depend on international support. Dependence on external actors creates a troubling imbalance of power; Tibetans essentially have to 'buy' their support by acting in the ways that the international community expects them to. Anand (2007) argues that the concept of Tibet has long offered a psychological sanctuary for westerners, who have consistently sought to believe in the possibility of a place of genuine peace on Earth (see also Lopez 1994, 1998). As long as Tibetans uphold this image of themselves as passive, spiritual people, they are likely to enjoy significant international popular support (although this has never translated into practical assistance by western states).

With this in mind, one is left to wonder whether the fervent religiosity with which Tibetans in Dharamsala explain acts of self-sacrifice could be reflective of their desire to maintain this 'Shangri-la' image in the international imagination, whether it is a true representation of local religious belief, or whether it is - as seems most likely - a complex combination of both. ${ }^{20}$

\section{Religious politics without the Dalai Lama?}

At this stage in the discussion, I would now like to return to Ardley's (2002) arguments about the future of this movement. She calls for the complete secularization of the political process, which would see the Dalai Lama maintaining a religious role with absolutely no political influence. The discussion above has shown that despite the Dalai Lama's retirement from political affairs in 2011 (nine years after Ardley (2002) made her arguments), people continue to link religion with political activity. However, the question remains: does the fact that people do not share the Dalai Lama's views on self-sacrifice, and yet still emphasize the importance of

\footnotetext{
20 While I believe that the religious beliefs of Tibetans in Dharamsala are genuine, this does not mean that other aspects of the 'Shangri-la' process are not operating. My experience does not suggest that Tibetans' religious beliefs necessarily make them feel 'innately' nonviolent or peaceful, for example, although they do promote these images of themselves in order to protect their international image. This is a very complex issue that relates not only to political ideas but to psychology, and I cannot do justice to a discussion of it here.
} 
religion in politics, mean that they are rejecting his personal influence over political processes?

It may seem difficult to imagine how people who have complete faith in the omniscience of a religious figure could see fit to disregard his ideas simply because they refer to political issues. People in Dharamsala certainly demonstrate this type of faith in the Dalai Lama in their everyday religious behaviour, and the results of the questionnaire reinforce this observation, with $96.1 \%$ of respondents either agreeing or strongly agreeing with the statement 'whatever the Dalai Lama says is correct.'

How, then, can they see fit to ignore some of his political assertions? The answer to this is inevitably complex. In her study of how human beings engage in political movements in apparently illogical ways, Wolford (2010: 25) emphasizes that we must add the fact that "people are "confused, life is complicated, emotional and uncertain" to our analyses of social change and mobilization'. Wolford (2010) is building here on Abu-Lughod's $(1993,2000)$ argument that social-scientific depictions of communities tend towards the static and homogenous, whereas they should aim to reveal the 'contestatory nature of discourses and social life within all communities' (Abu-Lughod 2000: 263). These are not discourses that compete against each other; they exist in parallel, finding homes in individual minds that manage to incorporate many of them at once, despite their opposing logics.

The main issue here relates to the politics of representation, and specifically to the assumption that 'other' cultures are comprised of uncontested beliefs and ways of doing things. Discursive contestation is in fact fundamental to all cultural groups, and more importantly this is not (only) factional but internal to each person. When we know that people in our own communities change their views/articulations fluidly depending on context and mood, why do we assume that the 'other' does not share this complexity?

The generalization of the 'other' in commentary, including academic writing, is located in power: its origins are in western professional, managerial and administrative processes that organise and control groups of 'others' within our own boundaries (e.g. the poor, women, prisoners). This, Abu-Lughod (1993) observes, is reflected in the social scientist's desire to uncover the 'truth' about the 'other' - the search for its elusive nature, or indeed for its unwavering logic, is dehumanising and rooted in our desire to control. 
Awareness of this is arguably the key to understanding how the Dalai Lama's spiritual authority functions. Abu-Lughod's $(1993,2000)$ insights can be linked to McGranahan's (2010b) observation of the difference in the Tibetan diaspora between the 'vicarious' reverence for scripture on the one hand (and one may infer institutionalised religion in general, including the institution of the Dalai Lama), and oral forms of knowledge that structure everyday behaviour on the other. McGranahan (2010b) notes that while the former is valued more highly in principle, it does not necessarily take precedence over the more ordinary discourses that people actually operate with, which are necessarily fluctuating and fragmentary. This perspective helps to explain Tibetans' widespread belief in the Dalai Lama's omniscience and their simultaneous capacity for everyday defiance of his discourse - albeit defiance at its margins (in its grey areas). Only by considering cultural functioning from this angle can we possibly hope to understand contradictory findings such as these, from the present study's questionnaire:

Fig. 3

\begin{tabular}{|l|l|l|l|l|l|}
\hline Question & $\begin{array}{l}\text { Strongly } \\
\text { Agree }\end{array}$ & Agree & Not Sure & Disagree & $\begin{array}{l}\text { Strongly } \\
\text { Disagree }\end{array}$ \\
\hline $\begin{array}{l}\text { I am a } \\
\text { religious } \\
\text { person }\end{array}$ & $53.9 \%$ & $37.3 \%$ & $5.9 \%$ & $1 \%$ & $1 \%$ \\
\hline $\begin{array}{l}\text { Whatever } \\
\text { HH the } \\
\text { Dalai } \\
\text { Lama } \\
\text { says is } \\
\text { correct }\end{array}$ & $74.5 \%$ & $21.6 \%$ & $2 \%$ & $1 \%$ & $1 \%$ \\
\hline
\end{tabular}

Fig. 4

\begin{tabular}{|l|l|l|}
\hline Question & Yes & No \\
\hline $\begin{array}{l}\text { Should politics and } \\
\text { religion be combined? }\end{array}$ & $74 \%$ & $26 \%$ \\
\hline
\end{tabular}

And yet, as highlighted earlier:

Fig. 5

\begin{tabular}{|l|l|l|}
\hline Question: & Violent & Nonviolent \\
\hline
\end{tabular}




\begin{tabular}{|l|l|l|}
\hline $\begin{array}{l}\text { Are hunger strikes a } \\
\text { violent or nonviolent } \\
\text { method of resistance? }\end{array}$ & $22.2 \%$ & $77.8 \%$ \\
\hline $\begin{array}{l}\text { Are self-immolations a } \\
\text { violent or nonviolent } \\
\text { method of resistance? }\end{array}$ & $22.5 \%$ & $77.5 \%$ \\
\hline
\end{tabular}

People's support for such acts is not indicative of a widespread ignorance of their leader's views, as McGranahan (2010) has already made clear. However, as the above results indicate, Tibetans who informed this study do not desire the Dalai Lama's removal from political thought processes, but rather emphasise that they wish to follow his example in their political decision-making. One common way of rationalising this apparent lack of coherence is revealed in common statements like this one:

'His Holiness must be right. But we are not all so perfect as he is. So we can only do what we can.'

People therefore acknowledge that anything the Dalai Lama advocates (or does not) must be correct, but in recognizing their own human frailties, they also accept that they are not always capable of living up to his standards. They forgive themselves, in other words, for their need to act in ways that reflect their own comparative spiritual inadequacies.

A further point to be made here, however, relates to a general vagueness in Dharamsala about the Dalai Lama's reasons for discouraging self-sacrificial methods. Although I presented this reasoning earlier in the article, he does not go into detail about it in ordinary and accessible public forums. It is not to be found in his public speeches, for example, but rather must generally be sought within his more philosophical writings. ${ }^{21}$ On the other hand, the Dalai Lama is vocal about his admiration for Gandhi (who personally lauded political self-suffering), without ever discussing their philosophical differences. For many people thinking about nonviolent resistance, therefore, to refer to Gandhi's logic is often thought to be essentially the

\footnotetext{
${ }^{21}$ We can only speculate on the reason behind the Dalai Lama's decision not to explain his reasoning in detail publicly. As noted earlier, his first reactions to the self-immolations mirrored his response to the hunger strikes: they were brave acts but ultimately they were violent (and thus undesirable) ones. In Jamyang Norbu's (2012: n.p.) words, 'he gave the impression that it wasn't a Buddhist thing to do.' As the self-immolations grew in number, however, his public pronouncements became more muted. He shifted to focus on the positive intentions of the self-immolators, and stopped referring to the violence of their acts (although he continued to plead with Tibetans not to self-immolate). As noted earlier, this is perhaps because the topic is an extremely sensitive one, and families and friends of self-immolators would be greatly impacted by an outright pronouncement of disapproval. .
} 
same as referring to the Dalai Lama's. For example, Al Jazeera journalists asked Tibetans in India: 'Isn't setting oneself on fire a violent action - something unacceptable in Tibetan Buddhism, which strictly advocates non-violence?' They quote a Tibetan refugee in response:

'Burning oneself for the freedom of six million Tibetans cannot bring negative karma. They do it for a selfless cause. So this is not against Buddhist beliefs...Gandhi also declared hunger strike unto death on many occasions. Does that make him violent? In every freedom struggle, violent or non-violent, people lose a part of themselves to attain a larger goal' (Gaedtke \& Parameswaran 2012: n.p.).

Indeed, the popularity of Gandhi's picture in shops/offices etc. is second only to the Dalai Lama's in Dharamsala, and everyone is aware of the Dalai Lama's great respect for the Indian leader. It is fairly straightforward, therefore, for people to set aside the Dalai Lama's anti-sacrifice message by assuming that it results from his innate kindness/compassion rather than from core doctrinal disagreements with Gandhi. Take the following quote from one of my interviews, for example:

'It is true that [the Dalai Lama] does not prefer self-immolation as a method. This is because he is so compassionate, he is the loving Chenrezig [the bodhisattva of compassion]. He cannot bear to see people suffer. But it is a great merit what these people have done.'

However, while the vagueness of the Dalai Lama's reasoning about political selfsacrifice allows for this type of digression from his views, there are other issues that do not lend themselves so easily to it. For example, Ardley (2002) also argued that the implementation of secular democracy would enable exiled Tibetans to replace the Dalai Lama's goal of regional autonomy with national independence, and she implied that they would certainly do so. This has not proven true so far; the official position has not changed since the Dalai Lama's retirement. According to this study, the majority of people in Dharamsala do believe that Tibet deserves to be an independent country:

Fig. 6

\section{Choose one of the following} options: 


\begin{tabular}{|l|l|}
\hline $\begin{array}{l}\text { Tibet should be a completely } \\
\text { independent country }\end{array}$ & $56.1 \%$ \\
\hline $\begin{array}{l}\text { Tibet should have meaningful } \\
\text { autonomy within China }\end{array}$ & $31.6 \%$ \\
\hline $\begin{array}{l}\text { Tibet should be the same as any } \\
\text { other Chinese state }\end{array}$ & $11.2 \%$ \\
\hline Nothing needs to change & $1 \%$ \\
\hline
\end{tabular}

However, those holding this view also regularly state that pursuing this goal would not be advisable. Some give practical reasons for this:

'If we waited another 50 years to get independence, everything we are fighting for - culture, religion, language - might be lost anyway.' Many, however, simply acknowledge that while they would instinctively prefer independence, they trust the Dalai Lama's opinion and therefore will continue to support meaningful autonomy.

Thus, Ardley (2002: 66)'s statement that 'the hunger strike in 1998 [and by association the recent support for self-immolation] is evidence of ....an increasing willingness to flout the Dalai Lama's stance on non-violence' is only partly correct. The word 'increasing' is certainly problematic, considering the long-term and widespread positive responses to hunger strikes. Furthermore, it must also be emphasized that as far as the non-activist population goes, the 'willingness to flout the Dalai Lama's stance on non-violence' extends only to subtle interpretations of what constitutes nonviolence, and not to a willingness to reject nonviolence altogether (see Fig. 1 above). Because the Dalai Lama has been so clear about the need for nonviolence, the vast majority of people are unwilling to compromise on this. Crucially, their continued insistence on nonviolence is a consequence of the Dalai Lama's teachings rather than just their own strategic judgment. The interviews conducted for this study asked people if they would support the Dalai Lama if he decided to advocate violence, and $70 \%$ of respondents said that they would. People are clearly still guided by the Dalai Lama's opinions, therefore, despite the official democratization of the political process.

The relevance of the Dalai Lama to Tibetan politics is likely to remain strong. Not only do Tibetans in Dharamsala have deep spiritual faith in the Dalai Lama, but they 
also view him as the 'glue' in their national struggle. The political situation requires a unified Tibetan population in exile, and the Dalai Lama, as a traditional institution as well as a man, "has far-reaching effects in terms of social cohesion - that is, to the idea that those who adopt, understand and use the same symbol can identify as members of the same community' (Bentz 2012: 291). Indeed, scholars including Bentz (2012) Kolas (1996) and Avedon (1984) remind us of the popular myth of Tibetan origin, in which the Dalai Lama in a prior incarnation as a monkey fathered the first Tibetans. He is therefore a symbol of Tibetanness that extends not only to religious authority but to the very existence of Tibetans as a people. In other words, the Dalai Lama 'not only provides continuity to the history of Tibet, but epitomises the community of Tibetans itself '(Kolas 1996: 57). Indeed, although most people in Dharamsala claim to have deep spiritual faith in the Dalai Lama, even people who do not focus on this still recognize the role that he plays in keeping the community together. As a member of Students for a Free Tibet emphasized tome, 'Religion and politics may not mix well as of right now, but... The Dalai Lama is the unifying force for Tibetans.' Thus, the Dalai Lama is not just a symbol of religious identity but a symbol of Tibet itself. This operates in the international sphere (he is, after all, the globally-recognized figurehead of this movement to liberate 'Shangri-la'), but also in the domestic arena in exile, where Tibetan refugees struggle to maintain a collective identity in an environment where foreign influences abound, and the diaspora is increasingly scattered.

\section{Conclusions: the future of the religion-politics relationship in Dharamsala}

As this paper draws to a conclusion, it will now reflect upon what the arguments and findings above imply for the future of Tibetan politics in exile. With the wisdom that hindsight now offers, it is easy to be doubtful of Ardley's (2002: 147) argument that democratization means that 'religion would be removed from practical political affairs.' The reality is that people in Dharamsala continue to seek religious justifications for political acts, perhaps especially when they appear to be in breach of other religious pronouncements.

It also seems reasonable to reject outright the idea that the Dalai Lama could somehow be ejected from the political imagination in Dharamsala. While counterdiscourses may be invoked to allow people to sidestep some of his pronouncements, other discourses are simultaneously maintained to preserve his position as an 
honoured spiritual leader - a 'God King', as he is often called. Critically, his position is not just that of a figurehead, but rather it is one that inspires deep religious and community sentiment in the population of Dharamsala - two things that are inextricably connected. While it may seem irrational for people to have such a depth of faith in the Dalai Lama whilst simultaneously appearing to ignore some of his political judgements, this must be accepted as an element of the natural fluidity of human cultural instinct.

It must be emphasised, moreover, that the apparent disregard for some of the Dalai Lama's views is located only in the grey areas of his discourse. The Tibetan leader's failure to be consistently explicit in public forums about his reasons for rejecting selfsacrifice creates these grey areas, leaving space for followers to (re)interpret his more general statements without explicitly challenging his traditional authority. Indeed, it seems likely that these fluid spaces are crucial to the entire relationship between faith and activism in this context.

Faith-based politics (in many instances, at least) is characterised by a combination of clear guidelines with pockets of intangibility: an instinctive yet non-elucidated sense of connection that skirts analytical process. Logic is neither necessary nor is it sought in this space, and it is for this reason that humans - Abu Lughod's (1993) 'confused, complicated and emotional' beings - can maintain a depth of faith that eludes academic comprehension, whilst occasionally acting and thinking in ways that seem to contradict their religious associations. In relation to Tibetan refugees I have argued that when issues are not locatable in these fluid, grey areas - where the choice would be starker ('I support the Dalai Lama or I do not' - e.g. the rejection of nonviolence in toto) - popular choices remain in favour of adhering to the Dalai Lama's views.

A related issue, and one more difficult to address, is what will happen after the Dalai Lama dies. At present he enjoys good physical and mental health, but at eighty years old he is nevertheless in the latter stages of life. The Dalai Lama has observed with sadness the fact that some people adhere to his methods as a marker of reverence to him, but may choose other paths after his death (cf. Kazmin 2013). Once he dies, it is also possible that the teachings of previous Dalai Lamas, including those of his immediate predecessor (who supported violence under certain circumstances) could also be re-invoked. Once the current Dalai Lama is no longer there to remind people regularly of his own views, it will certainly become easier for them to cling to counter discourses that legitimate alternative political methods 
within the broader cultural framework. Given the current trend, moreover, this seems distinctly likely.

If I were to predict a likely trajectory for this movement, it would be an increasing movement towards Gandhian methods within the broader framework of Tibetan Buddhism. The Dalai Lama is likely to maintain the positions of an object of worship and a symbolically unifying institution, but it seems likely that his rejection of common resistance methods that Gandhi favoured, including self-sacrifice and even extending to coercive tactics such as economic boycotts, may well be 'forgotten' or explained away after his death. The Dalai Lama's admiration for Gandhi, combined with an alternative view of skilful means that could permit virtually any form of political action with 'altruistic' intent (just as Gandhi could justify most acts if they were in the pursuit of 'Truth') has the potential to change how religion and politics interact here in future, while simultaneously preserving the orientalist images of Tibet necessary for international support. However, whether this could ultimately extend to the rejection of the Dalai Lama's central political positions (Ardley 2002) remains to be seen. At this point in time, it can only be concluded that the current prevalence and support of self-sacrifice does not indicate a secularisation process of Tibetan politics in exile, and nor does it indicate a truly significant move away from the Dalai Lama's political influence.

\section{References}

Abu-Lughod, L. (1993) Writing Women's Worlds. Berkeley, LA \& London: University of California Press.

Abu-Lughod, L. (2000) 'Locating Ethnography.' Ethnography 1 (2), pp. 261-267.

Anand, D. (2007) Geopolitical Exotica: Tibet in Western Imagination. Minneapolis: University of Minnesota Press.

Ardley, J. (2002) The Tibetan Independence Movement: Political, Religious and Gandhian Perspectives. London: RoutledgeCurzon.

Avedon, J. (1984) In Exile from the Land of Snows. London: Michael Joseph. 
Barnett, R. (1994) 'Symbols and Protest: The Iconography of Demonstrations in Tibet 1987 1990' in Barnett, R. \& S. Akiner (eds.) Resistance and Reform in Tibet. London: Hurst \& Company.

Barnett, R. (2012) 'Political Self-Immolation in Tibet and Chinese Popular Culture.' Revue d'Etudes Tibétaines 25, pp. 41-64.

Bentz, A-S. (2012) 'Symbol and power: the Dalai Lama as a charismatic leader.' Nations and Nationalism 18 920, pp. 287-305.

Buffetrille, K. (2012) 'Self-Immolation in Tibet: Some Reflections on an Unfolding History.' Revue d'Etudes Tibétaines 25, pp.1-17.

Clayton, B. (2006) Moral Theory in Santideva's Siksamuccaya. Abingdon: Routledge.

Dalai Lama (1994) A Flash of Lightening in the Dark of Night: A Guide to the Bodhisattva's Way of Life. Boston: Shambhala Publications Inc.

Fierke, K.M. (2013) Political Self-Sacrifice: Agency, Body and Emotion in International Relations (Kindle Edition). Cambridge: Cambridge University Press.

Gaedtke, F. \& Parameswaran, G. (2012) 'Tibet's Burning Protest.' Al Jazeera. Available at: http://www.aliazeera.com/indepth/features/2012/05/201253192951400741.html (accessed 05/06/14).

Gandhi, M.K. (2005) 'On Satyagraha' in Holmes, R.L. \& Gan, B.L. Nonviolence in Theory and Practice. Long Grove, Illinois: Waveland Press Inc.

Gyatso, P. (1997) Fire Under the Snow: Testimony of a Tibetan Prisoner. London: The Harvill Press.

ICT (International Campaign for Tibet) (2011) 'Powerful video footage, images of armed crackdown in 2008 across Tibet; Eyewitness account of militarization of Lhasa today.' Available at: http://www.savetibet.org/powerful-video-footage-images-of-armed-crackdown-in2008-across-tibet-eyewitness-account-of-militarization-of-Ihasa-today/\#sthash.KaEjTknF.dpuf (accessed 09/05/13).

Ingram, C. (1990) In the Footsteps of Gandhi. Berkeley: Parallax Press.

Ives, C. (2002) 'Dharma and Destruction: Buddhist Institutions and Violence.' Contagion: Journal of Violence, Mimesis and Culture 9, pp.151: 174.

Jerryson, M. \& Juergensmeyer, M. (eds.) (2010) Buddhist Warfare. New York: Oxford University Press.

Kazmin, A. (2013) 'An Exclusive Interview with the Dalai Lama.' Financial Times. Available at: http://www.ft.com/cms/s/2/d49d13aa-4749-11e3-b4d3-00144feabdc0.htm|\#slide0 (accessed 03/12/14).

Keown, D.V. (1992) The Nature of Buddhist Ethics. New York: Palgrave.

Khazan, O. (2012) 'China: Self-immolators and their abettors will be charged with murder.' The Washington Post. Available at: http://www.washingtonpost.com/blogs/worldviews/wp/2012/12/06/china-self-immolators-andtheir-abettors-will-be-charged-with-murder/ (accessed 01/02/15).

Kolas, A. (1996) 'Tibetan nationalism: the politics of religion'. Journal of Peace Research 33 (1), pp.51-66. 
Lixiong, W. (2012) 'Last-words analysis - Why Tibetans Self-immolate.' Phayul. Available at: http://www.phayul.com/news/article.aspx?id=32726 (accessed 12/06/14).

Lopez, D. S. Jr. (1998) Prisoners of Shangri-La: Tibetan Buddhism and the West. Chicago: University if Chicago Press.

Maher, D.F. (2010) 'Sacralized Warfare: The Fifth Dalai Lama and the Discourse of Religious Violence' in Jerryson, M. \& Juergensmeyer, M. (eds.) Buddhist Warfare. New York: Oxford University Press.

McGranahan, C. (2010) Arrested Histories: Tibet the CIA, and Memories of a Forgotten War. Durham \& London: Duke University Press.

McGranahan, C. (2010b) 'Narrative Dispossession: Tibet and the Gendered Logics of Historical Possibility.' Comparative Studies in Society and History 52 (4), pp. 768-797.

Norbu, J. (1986) [1979] Warriors of Tibet: The Story of Aten and the Khampas' Fight for the Freedom of their Country. London: Wisdom Publications.

Norbu, J. (1998) 'Rite of Freedom: The Life and Sacrifice of Thupten Ngodup.' Phayul. Available at: http://www.phayul.com/news/article.aspx?id=6853 (accessed 29/11/15)

Norbu, J. (2008) 'Remembering Thubten Ngodup.' Shadow Tibet (blog). Available at: http://www.jamyangnorbu.com/blog/2008/05/12/remembering-thupten-ngodup/ (accessed 01/11/14)

Norbu, J. (2012) 'Self-immolation and Buddhism.' Shadow Tibet (blog). Available at: http://www.jamyangnorbu.com/blog/2012/01/03/self-immolation-and-buddhism/ (accessed 28/11/15).

Saxena, S.K. (1976) 'The Fabric of Self-Suffering: A Study in Gandhi.' Religious Studies 12 (2), pp. 239-247.

Schmithausen, L. (1999) 'Aspects of the Buddhist Attitude Towards War' in Houben, J.E.M. \& Van Kooij, K.R. (eds.) Violence Denied: Violence, Nonviolence and the Rationalization of Violence in South Asian Cultural History. Leiden: Brill.

Schwartz, R.D. (1994) Circle of Protest: Political Ritual in the Tibetan Uprising. London: Hurst \& Company.

Shakya, T. (2012a) 'Transforming the Language of Protest.' Cultural Anthropology Online. Available at: http://www.culanth.org/fieldsights/94-transforming-the-language-of-protest

Shakya, T. (2012b) 'Self Immolation, the Changing Language of Protest in Tibet.' Revue d'Etudes Tibétaines 25, pp.19-40.

Sharp, G. (1973) The Politics of Non-Violent Action. Boston: Porter Sargent.

Shiromany, A.A. (ed.) (1998) The Political Philosophy of His Holiness the XIV Dalai Lama: Selected Speeches and Writings. New Delhi: Tibetan Parliamentary and Policy Research Centre.

Smith Jr., W. (2010) Tibet's Last Stand? Plymouth: Rowman \& Littlefield.

Sperling, E. (1994) 'The Rhetoric of Dissent: Tibetan Pamphleteers' in Barnett,R. \& S. Akiner (eds) Resistance and Reform in Tibet . London: Hurst and Co. 
TCHRD (2014) Human Rights Situation in Tibet: Annual Report. Available at: http://www.tchrd.org/category/annual-reports/ (accessed 01/06/15).

TCHRD (Tibetan Centre for Human Rights and Democracy) (2012) 'Full text of official notification punishing Tibetan self-immolations.' Available at:

http://www.tchrd.org/2012/11/full-text-of-official-notification-punishing-tibetan-selfimmolations/

Thinley, P. (2007) 'The Dalai Lama calls on Tibetans to end hunger strike: Day 31.' Phayul. Available at: http://www.phayul.com/news/article.aspx?id=17493 (accessed 12/03/2015). Victoria, B. (1997). Zen at War. New York: Weatherhill.

Victoria, B. (2010) 'A Buddhological Critique of "Soldier-Zen" in Wartime Japan' in Jerryson, M. \& Juergensmeyer, M. (eds.) Buddhist Warfare. New York: Oxford University Press.

Woeser (2012) 'Remembering the first person who self-immolated inside Tibet, Tapey.' Invisible Tibet (blog). Available at: http://woeser.middle-way.net/2012/02/blog-post 13.html (original Chinese version) or http://highpeakspureearth.com/2012/remembering-the-firstperson-who-self-immolated-inside-tibet-tapey-by-woeser/ (English translation).

Wolford, W. (2010) This Land is Ours Now: Social Mobilization and the Meaning of Land in Brazil. Durham \& London: Duke University Press.

WTNN (World Tibet Network News) (1998) 'India- Tibetan Protest.' Available at: http://www.tibet.ca/en/library/wtn/archive/old?y=1998\&m=4\&p=2 3 (accessed 15/06/15). 